\title{
Editorial
}

\section{EI desempleo en Colombia: una aproximación}

$\mathrm{U}$ no de los problemas más apremiantes actualmente en Colombia es la alta tasa de desempleo. Aunque, en realidad, este no es solo un problema para el país, porque uno de los objetivos macroeconómicos fundamentales de cualquier nación es contener el desempleo. Si bien es cierto que el nivel de desocupación debe ajustarse al tamaño y la composición de la economía analizada, la tasa de desempleo no debe exceder ciertos niveles, porque ello podría atentar contra la estabilidad política. De hecho, los costos de una alta tasa de desempleo en un país tienen que ver, entre otros, con los siguientes aspectos: 1) la reducción de la demanda agregada, porque en la medida en que los ingresos de la población disminuyen, baja la capacidad de compra de las personas, 2) aumento en los niveles de pobreza, debido a que una parte de la población económicamente activa no recibe ingresos. Además, dependiendo del nivel de desempleo y de su duración, la desocupación se puede convertir no solo en un problema social, sino también de salud pública.

Lo deseable sería que existiera "pleno empleo", pero este es un concepto económico, no físico, por lo que es imposible que toda la fuerza de trabajo esté plenamente ocupada. Por lo anterior, se alude a un desempleo de pleno empleo o estructural, para diferenciarlo del desempleo cíclico.

El desempleo en Colombia ha venido subiendo desde el año 2015. En el mes de octubre del 2019, la tasa de desempleo fue de $9.8 \%$, mientras que para el mismo mes de 2018 fue de $9.1 \%$. Según el DANE, la tasa de desempleo nacional del período agosto-octubre 2019 fue de $10.3 \%$, en tanto que en el mismo lapso de 2018 fue del $9.2 \%$, es decir, se registró un aumento de 1.1 puntos porcentuales. Por otro lado, la tasa de crecimiento de la economía para el tercer trimestre del año fue de $3.3 \%$, mientras que durante el mismo período de 2018 se ubicó en $2.6 \%$.

Además, podría esperarse que a medida que crezca la economía, el desempleo descienda. Esta relación la explica la teoría económica a través de la ley de Okun, llamada así en honor a Arthur Okun, asesor económico del presidente Kennedy, quien fue el primero en describirla e interpretarla. Esta relación postula que si la economía crece, es decir, si se incrementa la producción de bienes y servicios, se necesitan más factores productivos, entre ellos, mano de obra; sin embargo, en el caso colombiano, sobre todo en el último año, lo que se ha dado es contradictorio: un lento crecimiento con destrucción de empleo.

Para el director del DANE, la no correspondencia entre mayor crecimiento y menor desempleo se debe a la "mayor tecnificación de la estructura productiva del país". Según esta entidad, para producir mil millones de pesos en el PIB industrial en el 2015 se requerían 23,5 puestos de trabajo, mientras que en el 2018 esos requerimientos habían descendido a 21,9 plazas. La situación descrita se presenta en todos los sectores económicos, siendo más notoria en los sectores agrícola, información y comunicaciones, y comercio.

Una explicación plausible es que las innovaciones tecnológicas conducen a ahorrar mano de obra, pero dichos cambios se derivan de procesos y no de hechos inmediatos y, por ende, es válido lo que plantean algunos analistas del mercado laboral, como Stefano Farné y Juan Carlos Guataquí, quienes 
consideran que las transformaciones tecnológicas influyen en el mercado laboral, pero, subrayando, que dichos cambios se dan a largo plazo y no en pocos años o meses.

La pregunta por resolver es cómo reducir el desempleo. Según la ministra de Trabajo, dicho problema se resuelve por medio de la "flexibilización laboral, trabajo por horas con cotización, formación para el trabajo con pertinencia, iniciativa de equidad de género, Estado emplea, inclusión laboral, economía naranja y emprendimiento, entre otros". Si analizamos algunas de las iniciativas propuestas por la ministra, encontraremos que, en el pasado, no dieron los resultados esperados.

La flexibilización laboral se inició desde 1990 con el cambio de modelo económico. En dicho año se reformó la legislación laboral que, de una u otra forma, se expresó en la Ley 50 de 1990. Mediante dicha ley se modificó el régimen de cesantías y de despido; así mismo, les permitió a los empresarios despedir al trabajador en cualquier momento, siempre y cuando el empleador pagara la indemnización. Otro aspecto que se cambió con la reforma laboral fue la retroactividad de las cesantías, que posibilitó la creación de los fondos administradores de cesantías y pensiones. Con la nueva reglamentación se obligó a las empresas a consignar el mes de cesantías del año en un fondo de cesantías en entidades financieras, que le reconocería al trabajador el interés comercial sobre los saldos. Una vez hecho un retiro, este es definitivo y el saldo se reduce en ese mismo monto.

En la administración del presidente Uribe se diseñaron políticas que flexibilizaron aún más el mercado laboral. Estas iniciativas tenían que ver con la eliminación de los recargos por horas extras, pues se afirmaba que si se excluían, se generarían más empleos. Para alcanzar tal propósito, se modificó la jornada laboral y se permitió que esta se ampliara. Algunos estudios han demostrado que tal iniciativa no contribuyó a incrementar la ocupación, porque se hizo en contra de los trabajadores y en beneficio de los empleadores.

Por otro lado, la propuesta de contratar trabajadores por horas fue incorporada en el plan de desarrollo de la administración Duque. Así lo plantea el artículo 193 al vincular al piso de protección social a los trabajadores que tengan una relación contractual laboral o que se contraten por prestación de servicios, o de tiempo parcial, y que perciban un ingreso mensual inferior a un salario mínimo. Para la ministra de Trabajo, esta política contribuiría a aumentar el empleo, bajo el argumento de que "el mundo cambió, la gente trabaja por horas, a los muchachos no les gusta ni siquiera ir a la oficina, trabajan desde su casa. Digitalmente".

Es posible que la administración Duque, dado el alto desempleo informal, que representa aproximadamente el $60 \%$ en el sector urbano y el $80 \%$ en el sector rural, tenga buenas intenciones para reducirlo con la contratación por horas (“darles derechos a quienes no los tienen”), y así los trabajadores puedan tener acceso a prestaciones sociales, sin embargo, al legalizar la contratación laboral por horas o por debajo del mínimo, es posible que los empleadores incrementen ese tipo de contratos y desconozcan lo reglamentado en torno al salario mínimo y que, en definitiva, se afecten los ingresos de las personas más vulnerables.

Luis Eudoro Vallejo Zamudio Director de la Revista Apuntes del Cenes

Como citar: Vallejo Zamudio, L. (2020). El desempleo en Colombia: una aproximación. Apuntes Del Cenes, 39(69). Págs. 7 - 8 https://doi.org/10.19053/01203053.v39.n69.2020.10738 


\section{Editorial}

\section{Unemployment in Colombia: An Approach}

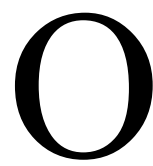

ne of the most pressing issues currently in Colombia is the high unemployment rate. Although, actually, this is not just a problem for the country, because one of the fundamental macroeconomic objectives of any nation is to contain unemployment. While it is true that the level of unemployment must conform to the size and the composition of the economy analyzed, the unemployment rate should not exceed certain levels, because this could undermine political stability. In fact, the costs of high unemployment in a country have to do, among others, with the following: 1) decreasing of aggregate demand, because to the extent that the income of the population declines, purchasing power of people decreases, 2) increasing in poverty levels, because a part of the economically active population does not receive income. In addition, depending on the level of unemployment and of its duration, unemployment can become not only a social problem but also of public health.

The desirable thing would be to have "full employment", but this is an economic concept not physical, so it is impossible that the entire workforce is fully occupied. Therefore, it refers to unemployment of full employment or structural, to differentiate it from cyclical unemployment.

Unemployment in Colombia has been rising since 2015. In October of 2019, unemployment rate was $9.8 \%$, while for the same month of 2018 it was $9.1 \%$. According to the DANE, the national unemployment rate for the period August-October 2019 was $10.3 \%$, while in the same period of 2018 it was $9.2 \%$, i.e. an increase of 1.1 percentage points was recorded. On the other hand, the economy growth rate for the third quarter of the year was $3.3 \%$, while during the same period of 2018 it was $2.6 \%$.

In addition, it might be expected that as economy grows, unemployment decreases. This relationship explains economic theory through the Okun law, named in honor of Arthur Okun, President Kennedy's economics adviser, who was the first one to describe and interpret it. This relationship postulates that if the economy grows, i.e., if production of goods and services increases, more productive factors are needed, including labor; however, in the Colombian case, especially in the last year, what has happened is contradictory: a slow growth with job destruction.

For the director of DANE, the lack of correspondence between higher growth and lower unemployment is due to the "greater technification of the country's productive structure". According to this entity, to produce one billion pesos in the industrial GDP in 2015, 23,5 jobs were required, while in 2018 those requirements had dropped to 21,9 jobs. The situation described is presented in all economic sectors, being more noticeable in the agriculture, information and communications, and trade sectors.

A plausible explanation is that technological innovations lead to save labor, but those changes are derived from processes rather than immediate facts and therefore it is valid as posed by some analysts of the labor market, as Stefano Farné and Juan Carlos Guataquí, who believe that 
technological changes affecting the labor market, but stressing that such changes occur in the long term and not in a few years or months.

The question to solve is how to reduce unemployment. According to the Minister of Labor, this problem is solved by means of the "labor flexibility, hourly workers, training with relevance, gender equity initiative, state employs, labor inclusion, orange economy and entrepreneurship, among others". If we analyze some of the initiatives proposed by the Minister, we find that, in the past, they did not get the expected results.

Labor flexibility has started since 1990 with the change of economic model. In that year labor law was reformed that, in one way or another, was expressed in the Law 50 of 1990. By means of said law severance and dismissal regime was modified; also, it allowed employers to dismiss a worker at any time, provided that the employer paid the compensation. Another aspect that changed with the labor reform was the retroactivity of severance pay, which enabled the creation of severance and retirement fund managers. With the new regulations, companies were obliged to deposit severance payments of the year in a severance fund in financial institutions, which would recognize the worker's commercial interest on the balances. Once a withdrawal is made, this is final and the balance is reduced by the same amount.

In the administration of President Uribe, policies were designed that made the labor market more flexible. These initiatives had to do with the elimination of surcharges for overtime, it stated that if they were excluded, more jobs would be generated. To achieve this purpose, the workday was modified and it was allowed to be extended. And some studies have shown that this initiative did not contribute to increase employment, because it was done against workers and for the benefit of employers.

On the other hand, the proposal to hire hourly workers was incorporated in President Duque's development plan. This is stated in article 193 by linking to the social protection floor workers who have a contractual employment relationship or who are hired for the provision of services, or part-time, and who receive a monthly income less than a minimum wage. For the Minister of Labor, this policy would help to increase employment, with the argument that "the world changed, people work hourly, young people do not even like going to the office, they work from home. Digitally".

It is possible that Duke administration, given the high informal unemployment, which represents approximately $60 \%$ in the urban sector and $80 \%$ in the rural sector, has good intentions to reduce it by hourly hiring ("giving rights to those who do not have them"), so that workers can have access to social benefits. However, by legalizing hourly hiring or below the minimum, employers may increase these types of contracts and ignore what is regulated on the minimum wage and, ultimately, affect the income of the most vulnerable people.

Luis Eudoro Vallejo Zamudio Director de la Revista Apuntes del Cenes

Como citar: Vallejo Zamudio, L. (2020). Unemployment in Colombia: An Approach. Apuntes Del Cenes, 39(69). Págs. 9 - 10 https://doi.org/10.19053/01203053.v39.n69.2020.10738 